\title{
Pengaruh Pemberian Pupuk Organik Cair dan Mikroorganisme terhadap Keasaman dan P-Tersedia pada Tanah Ultisol
}

\section{Effect of Liquid Organic Fertilizer and Microorganism to Acidity and P-Available on Ultisol Soil}

\author{
Kaya $\mathbf{E}^{1}$, Silahooy $\mathrm{Ch}^{1}$, Risambessy $\mathbf{Y}^{2}$ \\ 1) Dosen Jurusan Budidaya Pertanian Fakultas Pertanian Universitas Pattimura \\ 2) Alumni Fakultas Pertanian Universitas Pattimura \\ Jl. Ir. M. Putuhena, Kampus Poka Ambon (97234)
}

Kaya E, Silahooy Ch, Risambessy Y. 2017. Pengaruh Pemberian Pupuk Organik Cair dan Mikroorganisme terhadap Keasaman dan P-Tersedia pada Tanah Ultisol. Jurnal Mikologi Indonesia 1(2), 91-99.

\begin{abstract}
Abstrak
Tanah Ultisol yang digunakan dalam penelitian ini merupakan salah satu jenis tanah yang bermasalah dengan ketersediaan unsur $\mathrm{N}, \mathrm{P}$ dan $\mathrm{K}$ yang sangat rendah sampai rendah, Aluminium dapat ditukar (Al-dd) tinggi dan masam. Peningkatan produktivitas tanah dapat dilakukan melalui tindakan pemupukan dan penambahan mikroorganisme. Tujuan penelitian ini adalah untuk menganalisis pengaruh pupuk organik cair (POC) yang diberikan bersamasama dengan Trichoderma dan Azotobakter dalam meningkatkan $\mathrm{pH}$ dan P-tersedia tanah, serta menurunkan Al-dd tanah Ultisols. Penelitian ini adalah penelitian laboratorium yang dilakukan dari bulan Mei sampai September 2016. Penelitian ini dilakukan menggunakan percobaan faktorial dalam Rancangan Acak Lengkap, dimana POC terdiri dari 4 perlakuan: 0, 10, 20 dan $30 \mathrm{~mL} / \mathrm{L}$ dan isolat mikroorganisme terdiri dari 3 perlakuan: tanpa isolat, jamur Trichoderma dan bakteri Azotobacter. Hasil peneltian ini menunjukkan bahwa pemberian POC bersama-sama dengan isolat mikroorganisme antagonis dapat meningkatkan $\mathrm{pH}$ tanah (dari 4,43 menjadi 6,02), P-tersedia tanah (dari 9,33 ppm menjadi 32,00 ppm) dan menurunkan Aluminium dapat ditukar (Al-dd) tanah (dari 1,67 menjadi 0,39 cmol/Kg).
\end{abstract}

Kata Kunci - Ultisol- Pupuk Organik Cair-Trichoderma-Azotobacter.

\begin{abstract}
Ultisol is one of problematic soilsdue to containlow $N, P, K$, high Al-dd and acid pH (4.68). Increasing land productivity can be assisted through utilization of organic fertilizer and plant growth promoting microorganisms. The purpose of this study was to analyze the effect of liquid organic fertilizer in combination with selected strain of Trichoderma and Azotobacter to increase the $\mathrm{pH}$ and P-available soil, as well as to decrease Al-dd in ultisol soil. This study was conducted from May to September 2016. The experiments were designed using Completely Randomized Design where LOF consisted of 4 dose levels (0, 10, 20, $30 \mathrm{~mL} / \mathrm{L})$, while the microorganisms consisted of 3 levels (no isolates, Trichoderma, Azotobacter). The results showed that LOF application together with Trichoderma and Azotobacter isolates
\end{abstract}


increased soil pH (from 4.43 to 6.02), P-available soil (from 9.33to $32.00 \mathrm{ppm}$ ), and decreased Al-dd soil (from $1.67 \mathrm{To} 0.39 \mathrm{cmol} / \mathrm{Kg}$ ).

Keywords -Ultisol-Liquid OrganicFertilizer-Trichoderma-Azotobacter.

\section{Pendahuluan}

Tanah merupakan tempat tumbuh dan penyedia unsur hara bagi tanaman. Tanah yang baik dan subur adalah tanah yang mampu menyediakan unsur hara secara cukup dan seimbang untuk dapat diserap oleh tanaman, baik unsur makro maupun mikro (Yamani 2010). Dalam hubungan dengan tanah sebagai tempat tumbuh tanaman sekaligus penyedia unsur hara, tanah merupakan faktor utama yang sangat mempengaruhi pertumbuhan dan produksi tanaman. Oleh karena itu, kesuburan kimia tanah perlu dijaga dengan baik. Kesuburan kimia tanah meliputi ketersediaan kadar unsur hara tanah, kondisi keasaman tanah $(\mathrm{pH})$, kapasitas tukar kation (KTK) dan kejenuhan basa (KB).

Pada umumnya, tanah-tanah di Indonesia yang belum diusahakan maupun yang sudah diusahakan adalah tanah marginal yang bersifat asam, salah satunya yaitu tanah ultisol. Tanah ultisol merupakan tanah dengan ciri kandungan liat yang memperlihatkan horizon argilik dan kandungan bahan organik yang rendah. Tanah Ultisol merupakan tanah yang sudah mengalami podsolisasi yaitu proses translokasi horizon humus atas $\mathrm{Al}$ dan $\mathrm{Fe}$, dan umumnya berada di daerah tropis. Pusat Penelitian Tanah (PPT) menggolongkan tanah ultisol sebagai tanah Podsolik. Adanya timbunan Fe dan Al menyebabkan tanah ultisol berwarna merah sampai kuning. Menurut Soepardi (1983), tanah ini memiliki tingkat keasaman tanah yang tinggi dan kandungan unsur hara fosfor (P) yang rendah, serta daya fiksasi fosfat tinggi. Tingkat keasaman tanah berkisar antara 4-5. Kaya dkk (2010) melaporkan bahwa tanah ultisol/podsolik memiliki reaksi tanah yang asam ( $\mathrm{pH} 4,7)$, kandungan aluminium (Al) tinggi yaitu 3,47 me/100g, kesuburan kimiawi yang rendah atau miskin akan unsure hara dengan kejenuhan basa $11,0 \%$ dan KTK 19,75 me/100 g. Hal ini menyebabkan produktivitas tanahnya rendah sampai sedang, sehingga diperlukan teknologi pengelolaan yang baik untuk meningkatkan produktivitasnya. Beberapa tindakan perbaikan kesuburan tanah yang dapat dilakukan diantaranya melalui pemberian yaitu pupuk hayati, pupuk kandang, kompos, pupuk hijau, dan/atau pupuk organik cair (POC).

POC umumnya berasal dari bahan baku limbah pertanian seperti daun gamal, kulit buah pisang dan air cucian beras. POC mengandung bahan organik yang berperan aktif dalam meningkatkan reaksi pengikatan ion yang tersedia sehingga bisa langsung dimanfaatkan oleh tanaman (Hadisuwito 2012). Menurut Susanto (2002), penggunaan POC merupakan salah satu cara untuk mengatasi kekurangan bahan organik pada tanah, sehingga mampu memperbaiki sifat fisik, kimia dan biologi tanah. Penggunaan POC mampu meningkatkan ketersediaan $\mathrm{P}$, asam-asam organik seperti asam humat dan fulvat yang memegang peranan penting dalam pengikatan $\mathrm{Al}$ dan besi (Fe) (Utama dkk 2000). Akan tetapi, penggunaan POC harus dilakukan dengan konsentrasi yang tepat melalui serangkaian pengujian-pengujian di laboratorium dan lapangan (Rizqiani dkk. 2007).

Selain POC, mikroorganisme dapat digunakan untuk meningkatkan kesuburan tanah. Menurut Susilawati dkk. (2013) mikroorganisme tanah merupakan faktor penting dalam ekosistem tanah, karena berpengaruh terhadap siklus dan ketersediaan hara tanaman serta stabilitas struktur tanah. Mikroorganisme tanah berperan dalam proses penguraian bahan organik, melepaskan nutrisi dalam bentuk yang tersedia bagi tanaman, dan mendegradasi residu toksik, juga berperan sebagai agen peningkat pertumbuhan tanaman (plant growth promoting agents) yang menghasilkan berbagai hormon tumbuh, vitamin, dan berbagai asamasam organik yang berperan penting dalam merangsang pertumbuhan bulu-bulu akar. 
Mikroorganisme tanah yang diketahui bermanfaat bagi perbaikan kondisi tanah adalah jamur Trichoderma sp.dan bakteri Azotobacter sp.

Trichoderma sp. merupakan jamur yang umum terdapat dalam tanah, mudah beradaptasi, tumbuh dengan cepat, memiliki kemampuan antagonistik terhadap mikroorganisme lain, dan berfungsi sebagai organisme pengurai serta stimulator pertumbuhan tanaman (Chet 1987). Mekanisme antagonis jamur pada umumnya terjadi dengan cara kompetisi, mikoparasitik, dan antibiosis. Disamping memiliki kemampuan sebagai pengendali hayati, Trichoderma sp. memberikan pengaruh positif terhadap perakaran tanaman, pertumbuhan tanaman dan hasil tanaman. Bakteri Azotobacter adalah salah satu jenis bakteri aerobik gram negatif yang berperan sebagai penambat nitrogen $(\mathrm{N})$ diperakaran tanaman dan dipakai juga dalam pengendalian jamur patogen (Simanungkalit dkk. 2006). Azotobacter mengonversi $\mathrm{N}_{2}$ menjadi amonium melalui reduksi elektron dan protonasi gas dinitrogen. Unsur hara yang membatasi produktivitas tanaman adalah nitrogen sehingga pupuk nitrogen selalu ditambahkan sebagai input dalam produksi tanaman. Untuk menghindari penurunan kesehatan tanaman akibat adanya input bahan kimia, diperlukan input biologis berupa bakteri perakaran (rhizobacteria) (Hindersah dan Simarmata 2004). Azotobacter juga dapat menghasilkan hormon sitokinin pada kondisi bebas nitrogen, giberelin (Hindersah dan Simarmata 2004) dan auksin (Wedhastri 2002). Penelitian ini bertujuan untuk mengetahui pengaruh pemberian pupuk organik cair dan mikroorganisme (Trichoderma dan Azotobacter) terhadap sifat kimia tanah Ultisol.

\section{Metoda Penelitian \\ Rancangan Percobaan}

Penelitian dilaksanakan di Laboratorium Analisa Tanah, Air dan Tanaman, Fakultas Pertanian, Universitas Pattimura Ambon, berlangsung mulai dari bulan Juni sampai September 2016. Analisis kimia tanah dilakukan di Laboratorium Instalasi Tanah Maros. Penelitian dirancang menggunakan Rancangan Acak Lengkap (RAL) pola faktorial dengan menggunakan 2 faktor dengan tiga kali ulangan. Faktor pertama adalah Pupuk Organik Cair (POC) dengan 6 dosis perlakuan sebagai berikut: kontrol (C0), $10 \mathrm{~mL} / \mathrm{L}$ larutan $(\mathrm{C} 1), 20$ $\mathrm{mL} / \mathrm{L}$ larutan (C2), dan $30 \mathrm{~mL} / \mathrm{L}$ larutan (C5). Faktor kedua adalah isolat mikroorganisme antagonis (Trichoderma dan Azotobacter) yang terdiri atas: Tanpa isolat(A0), diinokulasi dengan Trichoderma(A1), dan diinokulasi dengan Azotobacter (A2). Data variabel respon yang dianalisis adalah sebagai berikut: $\mathrm{pH}$ tanah yang diukur adalah $\mathrm{pH} \mathrm{H}_{2} \mathrm{O}$ (2:1) dianalisis dengan menggunakan $\mathrm{pH}$ meter, P-tersedia dianalisis dengan menggunakan metode Bray dan Olsen danAl dapat ditukar (Al-dd) dengan menggunakan metode titrasi.

\section{Pupuk Organik Cair (POC)}

POC yang digunakan dalam penelitian ini disiapkan dengan Metode Fermentasi secara aerobik, yaitu dengan menggunakan bahan (daun gamal, kulit buah pisang): air beras dengan perbandingan 2:1 ditambah bioaktivator EM4, kemudian dimasukkan ke alat dekomposter dicampur hingga merata dan ditutup serta disambungkan menggunakan pipa berdiameter 0,5 inch ke jerigen berukuran 5 liter, dengan tujuan proses aerobik bisa berlangsung. POC diinkubasi selama 3 minggu sampai siap digunakan.

Mikroorganisme yang digunakan sebagai perlakuan adalah jamur Trichoderma harzianum dan bakteri Azotobacter chroococcum. Isolat T. harzianum ditumbuhkan pada media padat SDE (sekam, dedak, dan ela sagu/limbah olahan sagu) dengan perbandingan 1:1:1 selama 2 minggu. Isolat $A$. chroococcum ditumbuhkan pada media cair (molase) selama 1 bulan.Kedua isolat ini disimpan pada suhu kamar $\left(23-27^{\circ} \mathrm{C}\right)$. Populasi kedua mikroorganisme ini adalah $10^{9} \mathrm{cfu} / \mathrm{mL}$, kemudian diberikan ke dalam tanah $1 \mathrm{~kg}$ sebanyak 20 $\mathrm{mL}$ sesuai kombinasi perlakuan. 


\section{Hasil}

\section{Sifat Kimia Tanah awal Ultisol}

Tabel1 menunjukkan bahwa tanah dalam penelitian ini memiliki $\mathrm{pH}$ tergolong asam (4.68) dan kandungan $\mathrm{N}, \mathrm{P}, \mathrm{K}$ sangat rendah. Tanah dengan hasil analisa tersebut menunjukkan bahwa tingkat kesuburan tanah rendah dan jika ingin dimanfaatkan sebagai lahan pertanian guna mendapatkan hasil yang optimal maka perlu dilakukan upaya-upaya perbaikan melalui penambahan pupuk.

Tabel 1. Hasil Analisis tanah awal pada Tanah Ultisol (Podsolik)

\begin{tabular}{lll}
\hline \multicolumn{1}{c}{ Komponen yang dianalisis } & Nilai & Kriteria* \\
\hline $\mathrm{pH} \mathrm{H} \mathrm{H}_{2} \mathrm{O}$ & 4.68 & Asam \\
$\mathrm{Al}-\mathrm{dd}(\mathrm{cmol} / \mathrm{Kg})$ & 2.84 & Sangat rendah \\
$\mathrm{H}-\mathrm{dd}(\mathrm{cmol} / \mathrm{Kg})$ & 0.78 & \\
$\mathrm{C}-$-org $(\%)$ & 1.23 & Rendah \\
$\mathrm{N}-$ total $(\%)$ & 0.08 & Sangat rendah \\
$\mathrm{C} / \mathrm{N}$ & 15.4 & Tinggi \\
$\mathrm{P}$ tersedia $(\mathrm{ppm})$ & 14.0 & Sangat rendah \\
$\mathrm{K}$ tersedia $(\mathrm{ppm})$ & 23.0 & \\
Basa-basa dapat ditukar & & \\
$\mathrm{Ca}(\mathrm{cmol} / \mathrm{Kg})$ & 3.09 & Rendah \\
$\mathrm{Mg}(\mathrm{cmol} / \mathrm{Kg})$ & 0.71 & Rendah \\
$\mathrm{K}(\mathrm{cmol} / \mathrm{Kg})$ & 0.05 & Sangat rendah \\
$\mathrm{Na}(\mathrm{cmol} / \mathrm{Kg})$ & 0.06 & Sangat rendah \\
$\mathrm{KTK}(\mathrm{cmol} / \mathrm{Kg})$ & 10.56 & Rendah \\
$\mathrm{Kejenuhan} \mathrm{Basa}(\%)$ & 37.22 & Sedang \\
Tekstur $(\%)$ & & Termasuk \\
Pasir & 28.0 & \\
Debu & 20.0 & Liat \\
Liat & 52.0 & Jas \\
\hline
\end{tabular}

Ket: *Kriteria PPT,Hardjowigeno (2003)

\section{Sifat Kimia kandungan Pupuk Organik Cair (POC)}

Berdasarkan hasil analisis laboratorium mengenai kandungan unsur hara yang terkandung dalam POC yang dihasilkan dari proses fermentasi menunjukkan $\mathrm{pH}$ 6,67 (Tabel 2). Kandungan unsur tertinggi yaitu terdapat pada unsur kalsium $(\mathrm{Ca})$ yaitu $1.630 \mathrm{ppm}$ dan terkecil pada unsur $\mathrm{P}_{2} \mathrm{O}_{5}$ yaitu $0,07 \%$. Sedangkan kandungan $\mathrm{K}_{2} \mathrm{O}$ yang dihasilkan dari analisis laboratorium sebesar $0,76 \%$.

Tabel 2. Hasil Analisis awal pupuk organik cair

\begin{tabular}{ccc}
\hline Sifat Kimia & Nilai & Satuan \\
\hline $\mathrm{pH}$ & 6,67 & - \\
$\mathrm{N}$ & 0,63 & $\%$ \\
$\mathrm{P}_{2} \mathrm{O}_{5}$ & 0,07 & $\%$ \\
$\mathrm{~K}_{2} \mathrm{O}$ & 0,76 & $\%$ \\
$\mathrm{C}$ & 10,69 & $\mathrm{Ppm}$ \\
$\mathrm{Fe}$ & 9 & $\mathrm{Ppm}$ \\
$\mathrm{Zn}$ & 1 & $\mathrm{Ppm}$ \\
$\mathrm{Ca}$ & 1,630 & $\mathrm{Ppm}$ \\
$\mathrm{Mg}$ & 252 & $\mathrm{ppm}$ \\
$\mathrm{S}$ & 369 & $\mathrm{P}$ \\
\hline
\end{tabular}

Sumber: Hasil analisis Laboratorium Kaya dan Siregar tahun 2016, Dianalisis di Laboratorium Instalasi Tanah Maros.

\section{Sifat Kimia Tanah Setelah Penambahan POC dan Mikroorganisme}

Hasil analisis sidik ragam terlihat bahwa perlakuan POC dan mikroorganisme baik mandiri maupun interaksi keduanya dapat meningkatkan $\mathrm{pH}$ tanah. Pada Tabel 3 terlihat 
bahwa perlakuan POC tanpa mikroorganisme menunjukkan perbedaan dalam meningkatkan $\mathrm{pH}$ tanah. Makin tinggi dosis POC makin meningkat nilai $\mathrm{pH}$ tanah, tetapi bila POC diaplikasikan bersama-sama dengan mikroorganisme baik Trichoderma maupun Azotobaceter maka pengaruh pemberian POC untuk setiap dosis tidak berbeda dalam meningkatkan $\mathrm{pH}$ tanah, kecuali aplikasi POC dengan Azotobacter pada dosis $30 \mathrm{ml} / \mathrm{L}$ yang dapat meningkatkan $\mathrm{pH}$ tanah sampai 6,02.

Tabel 3. pH Tanah Akibat Perlakuan POC dan Mikroorganisme Pada Tanah Ultisol

\begin{tabular}{cccc}
\hline $\begin{array}{c}\text { Pupuk Organik Cair } \\
(\mathrm{C})\end{array}$ & \multicolumn{3}{c}{$\begin{array}{c}\text { Mikroorganisme } \\
(\mathrm{A})\end{array}$} \\
\hline & $\mathrm{A}_{0}$ & $\mathrm{~A}_{1}$ & $\mathrm{~A}_{2}$ \\
\cline { 2 - 4 } $\mathrm{C}_{0}$ & $4,43 \mathrm{a}$ & $5,08 \mathrm{a}$ & $5,02 \mathrm{a}$ \\
& $\mathrm{A}$ & $\mathrm{B}$ & $\mathrm{A}$ \\
$\mathrm{C}_{1}$ & $5,03 \mathrm{~b}$ & $5,07 \mathrm{a}$ & $5,17 \mathrm{a}$ \\
& $\mathrm{A}$ & $\mathrm{A}$ & $\mathrm{A}$ \\
$\mathrm{C}_{2}$ & $5,64 \mathrm{c}$ & $5,28 \mathrm{a}$ & $5,24 \mathrm{a}$ \\
& $\mathrm{A}$ & $\mathrm{A}$ & $\mathrm{A}$ \\
$\mathrm{C}_{3}$ & $5,12 \mathrm{~d}$ & $5,47 \mathrm{a}$ & $6,02 \mathrm{~b}$ \\
& $\mathrm{~A}$ & $\mathrm{~A}$ & $\mathrm{~B}$
\end{tabular}

Keterangan: Angka-angka yang ditandai dengan huruf yang berbeda ke arah setiap kolom (huruf biasa) dan ke arah baris (huruf kapital) adalah nyata menurut uji BNT $5 \%=0,51$

\section{Al dapat ditukar (Al-dd) Tanah}

Hasil analisis sidik ragam terlihat bahwa perlakuan POC dan mikroorganisme baik mandiri maupun interaksi keduanya dapat menurunkan Al-dd tanah. Pada Tabel 4 terlihat bahwa perlakuan POC untuk setiap dosis denganatau tanpa mikroorganisme menunjukkan perbedaan dalam menurunkan kadar Al-dd tanah. Sedangkan pengaruh pemberian POC dengan Trichoderma pada dosis $30 \mathrm{~mL} / \mathrm{L}$ berbeda nyata terhadap perlakuan tanpa dan diberi dosis $10 \mathrm{~mL} / \mathrm{L}$ larutan, tetapi tidak berbeda nyata dengan dosis $20 \mathrm{~mL} / \mathrm{L}$ larutan. Tetapi pemberian POC dengan Azotobacter pada perlakuan dosis $30 \mathrm{~mL} / \mathrm{L}$ berbeda nyata dengan tanpa, maupun diberi dosis POCpada konsentrasi 10 dan $20 \mathrm{~mL} / \mathrm{Ldalam}$ menurunkan Al-dd tanah. Dosis terbaik dalam menurunkan Al-dd tanah yaitu POC $30 \mathrm{~mL} / \mathrm{L}$ larutan dengan Azotobacter sebesar 0,39 cmol/Kg.

Tabel 4. Al-dd Tanah (Cmol/Kg) Akibat Perlakuan POC dengan Mikroorganisme Pada Ultisols

\begin{tabular}{cccc}
\hline $\begin{array}{c}\text { Pupuk Organik Cair } \\
(\mathrm{C})\end{array}$ & \multicolumn{3}{c}{ Mikroorganisme } \\
& $\mathrm{A}_{0}$ & $\mathrm{~A}_{1}$ & $\mathrm{~A}_{2}$ \\
\hline $\mathrm{C}_{0}$ & $1,67 \mathrm{a}$ & $1,54 \mathrm{a}$ & $1,24 \mathrm{a}$ \\
& $\mathrm{A}$ & $\mathrm{A}$ & $\mathrm{A}$ \\
$\mathrm{C}_{1}$ & $0,90 \mathrm{~b}$ & $1,21 \mathrm{a}$ & $1,16 \mathrm{a}$ \\
& $\mathrm{A}$ & $\mathrm{B}$ & $\mathrm{B}$ \\
$\mathrm{C}_{2}$ & $0,84 \mathrm{~b}$ & $0,72 \mathrm{~b}$ & $1,56 \mathrm{a}$ \\
& $\mathrm{A}$ & $\mathrm{A}$ & $\mathrm{A}$ \\
$\mathrm{C}_{3}$ & $0,69 \mathrm{~b}$ & $0,66 \mathrm{~b}$ & $0,39 \mathrm{~b}$ \\
& $\mathrm{~A}$ & $\mathrm{~B}$ & $\mathrm{C}$ \\
\hline
\end{tabular}

Keterangan: Angka-angka yang ditandai dengan huruf yang berbeda ke arah setiap kolom (huruf biasa) dan ke arah baris (huruf kapital) adalah nyata menurut uji BNT $5 \%=0,39$

\section{P-tersedia Tanah}

Hasil analisis sidik ragam terlihat bahwa perlakuan POC dan mikroorganisme baik mandiri maupun kombinasi keduanya dapat meningkatkan P-tersedia tanah.Pada Tabel 5 terlihat bahwa perlakuan POC $30 \mathrm{~mL} / \mathrm{L}$ larutan berbeda dengan atau tanpa diberi 10, 20, dan 
$30 \mathrm{~mL} / \mathrm{L}$ larutan dalam meningkatkan P-tersedia tanah. Tetapi pemberian POC dengan Azotobacter pada perlakuan dosis $30 \mathrm{~mL} / \mathrm{L}$ berbeda dengan tanpa, maupun diberi dosis POC konsentrasi 10 dan $20 \mathrm{~mL} / \mathrm{L}$ dalam meningkatkan Al-dd tanah. Dosis terbaik dalam meningkatkan P-tersedia tanah yaitu POC $30 \mathrm{~mL} / \mathrm{L}$ larutan dengan Azotobacter sebesar 32,00 $\mathrm{cmol} / \mathrm{Kg}$.

Tabel 5. P-Tersedia Tanah (ppm) Akibat Perlakuan Pupuk Organik Air dengan Mikroorganisme pada Tanah Ultisol

\begin{tabular}{cccc}
\hline $\begin{array}{c}\text { Pupuk Organik Cair } \\
(\mathrm{C})\end{array}$ & $\mathrm{A}_{0}$ & $\begin{array}{c}\text { Mikroorganisme } \\
(\mathrm{A})\end{array}$ \\
& $9,33 \mathrm{a}$ & $11,33 \mathrm{a}$ & $\mathrm{A}_{2}$ \\
\hline $\mathrm{C}_{0}$ & $\mathrm{~A}$ & $\mathrm{~A}$ & $11,00 \mathrm{a}$ \\
& $10,67 \mathrm{a}$ & $17,00 \mathrm{~b}$ & $\mathrm{~A}$ \\
$\mathrm{C}_{1}$ & $\mathrm{~A}$ & $\mathrm{~B}$ & $19,00 \mathrm{~b}$ \\
& $11,33 \mathrm{a}$ & $12,00 \mathrm{c}$ & $24,00 \mathrm{c}$ \\
$\mathrm{C}_{2}$ & $\mathrm{~A}$ & $\mathrm{~A}$ & $\mathrm{~A}$ \\
& $16,00 \mathrm{c}$ & $23,00 \mathrm{~d}$ & $32,00 \mathrm{~d}$ \\
$\mathrm{C}_{3}$ & $\mathrm{~A}$ & $\mathrm{~B}$ & $\mathrm{C}$ \\
\hline
\end{tabular}

Keterangan : Angka-angka yang ditandai dengan huruf yang berbeda ke arah setiap kolom ( huruf biasa ) dan ke arah baris ( huruf kapital) adalah nyata menurut uji BNT $5 \%=3,26$

\section{Pembahasan}

Menurut klasifikasi USDA (2006), tanah yang digunakan dalam penelitian ini tergolong tanah ultisol (Tabel 1). Dalam laporan sebelumnya, tanah yang terdapat di dusun Talaga Kodok tergolong tanah ultisol (Kaya dan Siregar 2016). Hal ini sesuai dengan ciri-ciri tanah ultisol, di mana proses pencucian telah berlangsung intensif dengan kandungan basa-basa dapat ditukar yang rendah dan kandungan bahan organic yang rendah (Mahbub dkk, 2011). Mineral-mineral utama melapuk dan unsur-unsur di dalamnya terlepas, selanjutnya hilang terbawa air perkolasi sehingga tanah ultisol mempunyai produktivitas yang tergolong rendah (Sanchez 1992).

Kandungan unsur hara yang terkandung dalam POC yang dihasilkan dari proses feermentasi menunjukkan pH 6.67 (Tabel 2). Kandungan unsur hara yang terkandung dalam POC yang dihasilkan dari proses fermentasi menunjukkan $\mathrm{pH} 6.67$ (Tabel 2). Menurut Indriani (2002), kisaran pH yang baik bagi POC yaitu sekitar 6.5-7.5 (netral). Kandungan unsur kalium (K) dari POC pada penelitian ini $(0.76 \%)$ sudah memenuhi standar baku mutu POC yaitu $0.20 \%$ (Sundari dkk. 2012). Hal tersebut menunjukkan bahwa kandungan kalium yang dihasilkan dari POC dalam penelitian ini sudah memenuhi batas minimum yang dibutuhkan tanaman. POC dikatakan baik dan siap diaplikasikan jika tingkat kematangan fermentasinya sempurna, diketahui dari keadaan bentuk fisiknya, dimana fermentasi yang berhasil ditandai dengan adanya bercak-bercak putih pada permukaan cairan, warna cairan yang dihasilkan pada proses pemeraman cairan adalah coklat muda dengan bau yang tidak menyengat, dan $\mathrm{pH}$ mendekati netral. Sutanto (2012) menambahkan bahwa biasanya $\mathrm{pH}$ agak turun pada awal proses fermentasi karena aktivitas bakteri yang menghasilkan asam. Dengan munculnya mikroorganisme lain dari bahan yang didekomposisikan, maka $\mathrm{pH}$ bahan akan naik setelah beberapa hari dan kemudian berada pada kondisi netral.

Pemberian bahan organik mampu meningkatkan nilai $\mathrm{pH}$ tanah, karena bahan organik memiliki kemampuan mengikat logam $\mathrm{Al}^{3+}$, sehingga tidak terjadi reaksi hidrolisis $\mathrm{Al}^{3+}$, dimana dari reaksi hidrolisis $\mathrm{Al}^{3+}$ dihasilkan 3 ion $\mathrm{H}^{+}$yang dapat mengasamkan tanah (Nariratih dkk. 2013). Pada tanah-tanah asam pemberian bahan organik dapat meningkatkan pH tanah (menetralkan Al dengan membentuk kompleks Al-organik). Hal ini diduga juga karena kemampuan kompos mengadsorbsi kation, termasuk $\mathrm{H}^{+}$sehingga keasaman tanah 
berkurang dan $\mathrm{pH}$ menjadi meningkat. Menurut Sugiyanto dkk. (2005) hasil perombakan bahan organik akan menghasilkan kation-kation basa seperti $\mathrm{Ca}, \mathrm{Mg}, \mathrm{K}$, dan $\mathrm{Na}$ yang mampu meningkatkan $\mathrm{pH}$. Pelepasan kation-kation basa ke dalam larutan tanah akan menyebabkan tanah jenuh dengan kation-kation tersebut dan pada akhirnya akan meningkatkan $\mathrm{pH}$ tanah.

Hasil penelitian juga menunjukkan bahwa terjadi penurunan kadar Al-dd dan meningkatkan P-tersedia tanah setelah ditambahkan POC dan mikroorganisme. Hal ini umumnya terjadi karena adanya proses dekomposisi yang selanjutnya menghasilkan asam humat dan fulvat sehingga $P$ yang terikat dapat dilepaskan. Bahan organik yang diberikan ke dalam tanah melalui proses dekomposisi akan menghasilkan banyak asam organik yang mengandung turunan-turunan asam fenolat dan asam karboksilat (Wahjudin 2006). Hastuti (2003) mengungkapkan bahwa hasil penguraian bahan organik menghasilkan asam humat dan asam fulvat sehingga P-terikat dapat dilepaskan dan menjadi tersedia dalam tanah.Bahan organik tanah dapat membentuk ikatan yang kompleks dengan Al terlarut, sehingga ikatan $\mathrm{P}$ oleh Al menjadi berkurang (Sanchez 1992). Peningkatan pH dan penurunan Al-dd terjadi karenapupuk organikdan mikroorganisme mampu meningkatkan proses dekomposisi selain menghasilkan unsur-unsur hara yang tersedia bagi tanaman (Yassen dkk. 2010). Asam-asam organik membentuk senyawa komplek dengan Al dalam larutan tanah sehingga mengurangi kelarutan dan toksisitas Al terhadap tanaman (Haynes dan Mokolobate, 2011).

Terjadinya peningkatan $\mathrm{pH}$ dan $\mathrm{P}$ tersedia tanah disebabkan karena adanya aktivitas mikroorganisme tanah yang meningkat, sehingga terjadi proses dekomposisi dan mineralisasi senyawa organik lebih banyak dan mampu mengikat logam-logam seperti $\mathrm{Fe}, \mathrm{Al}$ dan $\mathrm{Mn}$, juga mampu melepaskan sejumlah ion $\mathrm{P}$ sehingga menambah ketersediaannya di dalam tanah. Peningkatan ketersediaan $\mathrm{P}$ dengan adanya bahan organik dan inokulasi mikroorganisme disebabkan mikroorganisme tanah mengatur siklus unsur hara melalui cara mempengaruhi proses dekomposisi bahan organik yang mempengaruhi pelepasan dan retensi unsur hara. Dari hasil penguraian, selain melepaskan N, Azotobacter juga membantu melepaskan ikatan $\mathrm{P}$ yang berdampak meningkatknya P-tersedia dalam tanah (Hasanudin 2003). Sedangkan jamur Trichoderma umumnya berkoloni dengan akar dan membantu tanaman induk menyerap berbagai unsur hara tertentu, terutama fosfat (Subhan dkk. 2008).

Berdasarkan hasil penelitian yang dilakukan maka dapat disimpulkan bahwa pemberian pupuk organikcair (POC) bersama-sama dengan mikroorganismeterpilih (Trichoderma dan Azotobacter)dapat menurunkan Al-dd (dari 1.67 menjadi $0.39 \mathrm{cmol} / \mathrm{kg}$ ), meningkatkan $\mathrm{pH}$ (dari 4.68 menjadi 6.02) danketersediaan $\mathrm{P}$ (dari $14.00 \mathrm{ppm}$ menjai $32.00 \mathrm{ppm}$ ) di tanah ultisol.

\section{Pustaka}

Chet I. 1986-Innovative approach to Plant Disease Control.The Hebrew University of Jerusalem, Faculty of agriculture. Rehovot, Israel. John wiley and Sons.New York.11210.

Hadisuwito S. 2012-Membuat Pupuk Organik Cair. Agromedia Pustaka. Jakarta.

Hasanudin 2003. Peningkatan Ketersediaan dan Serapan N dan P serta hasil tanaman jagung melalui inokulasi Mikoriza, Azotobacter dan Bahan Organik pada Ultisol. Jurnal Ilmu Pertanian Indonesia 5.83-89.

Hastuti2003-Pengaruh berbagai jenis bahan Amelioran terhadap pertumbuhan dan hasil tanaman Sorgum di Jawa Timur. http://repository.ipb.ac.id/bitstream/handle/20IV_A93atr.pdf.Diakses 9 Desember 2013.

Haynes R.J, Mokolabate MS. 2011-Amelioration of Al toxicity and P deficiency in acid soil by addittions of organic residues: A Critical review of the phenomenon and the mechanisms involved. Nutr.Cycl.Agroecosyst. 59:47-63 
Hindersah R, Simarmata T. 2004-Kontribusi Rhizobacteria azotobacter dalam meningkatkan kesehatan tanah melalui fiksasi $\mathrm{N}_{2}$ dan produksi fitohormon di rizosfir. Jurnal Natur Indonesia 6, 127-133.

Indriani YH. 2002- Membuat Kompos secara Kilat, Cetakan 4. Penebar Swadaya, Jakarta. Jayadi, M. 2009. Pengaruh pupuk organik cair daun gamal dan pupuk anorganik terhadap pertumbuhan tanaman jagung. Makassar: Universitas Hasanuddin. Jurnal Agrisistem 5 (2), 61-67

Kaya E, Putinella JA, Puturuhu F. 2010- Pengaruh Pemberian Kompos Ela Sagu dan Pupuk SP-36 terhadap Perilaku P dalam Tanah, Serapan P, serta Hasil Jagung (Zea mays L.) pada Ultisols. Laporan Penelitian (Penelitian Hibah Multi Year T.A. 2010 dibiayai oleh Direktorat Jenderal Pendidikan Tinggi, Departemen Pendidikan Nasional, Sesuai Surat Perjanjian Pelaksanaan Penelitian Hibah Penelitian Nomor : 018/SP2H/PP/DP2M/III/2010, tanggal 01 Maret 2010). Fakultas Pertanian Universitas Pattimura. Ambon.

Kaya E, Siregar A. 2016- Pengaruh Pupuk Organik terhadap Sifat Kimia dan Fisik Tanah, serta Serapan, Pertumbuhan dan Produksi Tanaman Jagung (Zea mays L) pada Ultisols. Laporan Penelitian (Hibah Penelitian Pascasarjana yang Dibiayai dengan Dipa Dikti sesuai perintah Perjanjian Kerja No. 045/SP2H/PL/DIT.LITABMAS/II/2015, tanggal 5 Februari 2015).Fakultas Pertanian Universitas Pattimura. Ambon

Mahbub IA, Muzar A, Ermadani. 2011- Pengaruh residu kompos tandan buah kelapa sawit tehadap beberapa sifat kimia Ultisol dan hasil kedelai.Jurnal Penelitian Universitas Jambi Seri Sains, 13, 11-18.

Nariratih I, Damanik MMB, Sitanggang G. 2013- Ketersediaan Nitrogen pada 3 jenis tanah akibat pemberian 3 bahan organik dan serapannya pada tanaman Jagung. Jurnal Agroekoteknologi 1, 479-488.

Rizqiani NF, Ambarwati E,Yuwono NW. 2007- Pengaruh dosis dan frekuensi pemberian Pupuk Organik Cair terhadap pertumbuhan dan hasil Buncis (Phaseolus vulgaris L.) Dataran Rendah. Jurnal Ilmu Tanah dan Lingkungan 7, 43-53.

Sanchez PA. 1992- SifatdanPengolahan Tanah Tropika.Penerbit ITB. Bandung.

Simanungkalit DA, Saraswati R, Hastuti RD, Husen E. 2006. Bakteri Penambat Nitrogen. Balai Besar Litbang Sumber Daya Lahan Pertanian. Badan Penelitian dan Pengembangan Pertanian. Bogor.

Soepardi G. 1983- Sifat dan Ciri Tanah. Jurusan Tanah. Fakultas Pertanian IPB. Bogor

Subhan F, Hamzah, Wahab A. 2008- Aplikasi bokashi kotoran ayam pada tanaman melon. Jurnal Agrisistem 4, 1-10.

Sugiyanto, Sugiyono, Wibawa A. 2005- Status hara tanah di perkebunan kopi dan kakao di Jawa Timur (Periode 2000-2005). Warta Pusat Penelitian Kopi dan Kakao 21, 120 124

Sundari E, Sari E, Rinaldo R. 2012- Pembuatan Pupuk Organik Cair Menggunakan Bioaktivator Biosca dan EM-4. Prosiding STNK TOPI 2012, Pekanbaru, 11 Juli 2012: p 93-97

Susilawati, Mustoyo, Budhisuyra E, Anggono RCW, Simanjuntak BH. 2013. Analisis kesuburan tanah dengan indikator mikroorganisme tanah pada berbagai sistem penggunaan lahan di plateau dieng. Jurnal Ilmu Pertanian 25 No.1, Des. 2013: p 64-67

Sutanto S. 2012. Pertanian Organik. Kanisius, Yogyakarta.

USDA (United States Department of Agriculture). 2006. Soil Taxonomy. USDA Publiser, New York. 
Wahjudin UM. 2006. Pengaruh pemberian kapur dan komposisi tanaman terhadap Aluminium dapat ditukar dan produksi tanaman Kedelai pada tanah Vertic Hapludult dari Gajrug, Banten. Jurnal Agronomi Indonesia (34) (3) 2006: p. 141-147

Wedhastri W. 2002. Isolasi dan seleksi Azotobacter spp penghasil tanda tumbuh dan penambat Nitrogen dari tanah asam. Jurnal Ilmu Tanah dan Lingkungan 3:45-51.

Yamani A. 2010. Analisis kadar hara makro dalam tanah pada tanaman agroforestri di desa tambun Raya Kalimantan Tengah. Jurnal Hutan Tropis 11:37-46.

Yassen AA, Khaled SM, Sahar, Zaghloul M. 2010. Response of wheat to different rates and ratios of organic residues on yield and chemical composition under two types of soil. J. Am. Sci. 6: 858-864. 